\title{
COMPARATIVE STUDY ON ANTIMICROBIAL ACTIVITY OF TULSI (OCIMUM SANCTUM) AND NEEM (AZADIRACHTA INDICA) METHANOL EXTRACT
}

\author{
VIPUL KUMAR ${ }^{1,2}$, ANURAG CHAKRABORTY ${ }^{1}$, MANPREET KAUR ${ }^{1}$, SONY PANDEY ${ }^{1}$, MANOJ KUMAR JENA ${ }^{1 *}$
}

${ }^{1}$ Department of Biotechnology, School of Bioengineering and Biosciences, Lovely Professional University, Punjab, India. ${ }^{2}$ Department of Biochemical Engineering and Biotechnology, Indian Institute of Technology, Delhi, India. Email: manoj.20283@lpu.co.in

Received: 25 July 2018, Revised and Accepted: 25 September 2018

\section{ABSTRACT}

Objective: This study was focused on to compare the antimicrobial activity of methanolic leaf extracts of tulsi and neem.

Methods: We have chosen tulsi (Ocimum sanctum) and neem (Azadirachta indica) to compare their antimicrobial activity toward Gram-positive (Staphylococcus aureus) and Gram-negative (Escherichia coli) bacteria. Phytochemical extracts have been made by the use of methanol as solvent and dried leaf powder by the cold maceration extraction process. Phytochemical analysis for some secondary metabolites has been done using standard protocols. Nutrient agar plates were inoculated with the above-mentioned microorganisms by spreading bacterial inoculum on the surface of the media. Wells (6 $\mathrm{mm}$ in diameter) were punched in the agar. The phytochemical extracts of neem and tulsi were allowed to diffuse into the medium, and after incubation of $24 \mathrm{~h}$ at $37^{\circ} \mathrm{C}$, the zones of inhibition were observed.

Results: Statistical analysis showed that tulsi was more effective toward S. aureus while neem was more effective toward E. coli. Minimum inhibitory concentration (MIC) of tulsi for both the microorganisms was $0.4 \mathrm{~g} / \mathrm{ml}$, and the MIC of neem for both the microorganisms was $0.2 \mathrm{~g} / \mathrm{ml}$. When both the tulsi and neem extract were mixed with each other for every concentration at equal volume, they have shown better effects in comparison to individual neem or tulsi extract and also the MIC got reduced to $0.2 \mathrm{~g} / \mathrm{ml}$ for both the bacteria.

Conclusions: Leaf extracts of both the A. indica and $O$. sanctum have shown antimicrobial activity against $E$. coli and $S$. aureus. A. indica has higher antimicrobial activity against $S$. aureus, whereas the $O$. sanctum was found to be more effective against $E$. coli (indicated by the zone of inhibition). When both the extracts were mixed with each other, they have shown a better effect toward both bacteria.

Keywords: Minimum inhibitory concentration, Tulsi, Neem, Phytochemical, Zone of inhibition.

(c) 2018 The Authors. Published by Innovare Academic Sciences Pvt Ltd. This is an open access article under the CC BY license (http://creativecommons. org/licenses/by/4. 0/) DOI: http://dx.doi.org/10.22159/ajpcr.2018.v11i12.28756

\section{INTRODUCTION}

Azadirachta indica, an eminent and sacred gift of nature, is commonly known as neem, and it is mainly cultivated in the tropical regions of the Indian subcontinent, The Latinized name of neem, $A$. indica, is derived from the Persian word "Azad" means free, "dirakht" means tree, and "i-Hind" means of Indian origin. Hence, it literally means "the free tree of India" [1]. Neem is a member of the Meliaceae family. Neem possesses many constituents that are of great importance for the treatment of various diseases, and the constituents also modulate the genetic pathways or metabolic activities of the host body [2]. Neem is widely used in the field of pharmaceuticals, agriculture, as fertilizer, etc., due to the presence of biologically important phytochemicals [3]. Acetone extract and chloroform extract of neem leaf found to be a strong candidate for cancer therapy and as strong antibiotics against pathogenic bacteria [4]. Flavonoids are used in food and beverages of plant origin, such as tea, cocoa, and wine, and hence, they are also called dietary flavonoids [5].

Ocimum sanctum, commonly known as tulsi or holy basil, has been used since ages in Ayurveda due to its healing property. It is also known as "queen of herbs" and is one of the holiest herbs in India with Kingdom - Plantae, Subkingdom - Tracheobionta, Superdivision - Spermatophyta, Division - Magnoliophyta, Class - Magnoliopsida, Subclass - Asteridae, Order - Lamiales, Family - Lamiaceae, Genus - Ocimum, and Species - O. sanctum. Due to its powerful savor, it is regarded as the elixir in Ayurveda and believed to promote lifespan. The extract of tulsi is commonly known for the treatment of cold, headache, stomach disorders, etc. [6]. O. sanctum extract shows anticancer activity by decreasing cell proliferation, increasing reactive oxygen species, and by altering mitochondrial membrane potential [7]. Since ages dried leaves of tulsi have been used for repeling inscects in grains. Tulsi has been effective in improving the lipid profile and basal metabolic rate [5]. The study of immune diffusion and inflammation shows that intake of a leaf extract before food can increase immune response by increasing the level of helper $\mathrm{T}$ cells and natural killer cells.

Escherichia coli, Gram-negative bacteria, is the major cause of diarrheal diseases, peritonitis, colitis, and infant mortality [8]. E. coli acquires its pathogenicity through virulence factors [9]. In the serious case of diarrhea, the patient may end up with bloody diarrhea or hemorrhagic colitis and can become life threatening. E. coli responsible for urinary tract infection has become resistant to the drug that has been used to cure it, so need of new and plant extract as a medicine is increasing several folds, whereas Staphylococcus aureus, which is a Gram-positive bacteria (member of Firmicutes), can cause life-threatening diseases such as sepsis, endocarditis, and pneumonia. S. aureus is prevalent in the sites of wastewater treatment plants. S. aureus is considered notorious due to its ability to become drug resistant and resistant to antibiotics such as penicillin and methicillin.

There is an enormous increase in antibiotic resistance among bacteria over a period of time due to evolution, adaptation, and overuse of synthetic drugs against them. Hence, there is always a need of developing potent antimicrobial drugs against them, and due to huge plant diversity and phytochemicals possessing secondary metabolites having antimicrobial activity, it can be a great alternative for synthetic drugs due to its cheaper cost and fewer side effects [10]. We can use these plants as a special formulation for preventing and curing various infections and 
diseases. Formulations can be used in food and pharmaceutical industry effectively. Among various microbial health threats, S. aureus is the most common for skin infections and septicemia, and pathogenic strains of E. coli can lead to various diseases such as diarrhea, vomiting, and nausea.

\section{METHODS}

\section{Plant leaf collection}

The leaves of $A$. indica (neem) and $O$. sanctum (tulsi) were collected from Botanical Herbal Garden, Lovely Professional University, Phagwara, Punjab. Leaves were manually separated, cleaned, and air-dried for 4-5 days. Subsequently, the leaves were pulverized to a coarse powder through mortar and pestle. Approximately 50 g powder of both the leaves was weighed and stored in an airtight bottle [10]

\section{Preparation of extracts}

About $250 \mathrm{ml}$ of methanol was added in a separate conical flask with $50 \mathrm{~g}$ of each leaves powder to make a stock solution of $0.2 \mathrm{~g} / \mathrm{ml}$ concentration using a cold maceration extraction process. Afterward, working solution of each extract at concentrations such as $0.2 \mathrm{~g} / \mathrm{ml}$, $0.3 \mathrm{~g} / \mathrm{ml}, 0.4 \mathrm{~g} / \mathrm{ml}, 0.5 \mathrm{~g} / \mathrm{ml}, 0.6 \mathrm{~g} / \mathrm{ml}$, and $0.7 \mathrm{~g} / \mathrm{ml}$ was prepared on the basis of the formula "C1V1=C2V2."

Where,

C1=Concentration of stocks solution,

$\mathrm{C} 2=$ Final concentration of a new solution,

V1=Volume of stock solution,

V2=Final volume of new solution

Then, mix solutions of neem and tulsi were also prepared at concentrations of $0.2 \mathrm{~g} / \mathrm{ml}, 0.3 \mathrm{~g} / \mathrm{ml}, 0.4 \mathrm{~g} / \mathrm{ml}, 0.5 \mathrm{~g} / \mathrm{ml}, 0.6 \mathrm{~g} / \mathrm{ml}$, and $0.7 \mathrm{~g} / \mathrm{ml}$ by mixing of each extract concentration at $1: 1$ ratio.

\section{Test organisms}

Two bacterial cultures were used to evaluate the antimicrobial activity: E. coli (MTCC40) and S. aureus (MTCC740) from the stock of Microbiology Laboratory of Lovely Professional University.

\section{Antimicrobial activity test}

Nutrient agar plates were inoculated with the above-mentioned microorganisms by spreading the bacterial inoculum on the surface of the media (spread plate technique). Wells ( $6 \mathrm{~mm}$ in diameter) were punched in the agar [11]. $50 \mu \mathrm{l}$ extract of neem, tulsi, and their mixture of each concentration is allowed to diffuse out into the agar medium in separate Petri dishes, after incubation of $24 \mathrm{~h}$ at $37^{\circ} \mathrm{C}$, the zones of inhibition were observed uniformly circular as there was a confluent lawn of growth. Moreover, finally, the diameter of the zone of inhibition (ZOI) was measured in millimeters by Vernier scale [12].

\section{Phytochemical analysis}

Test for tannin

In $2 \mathrm{ml}$ of aqueous extract $\mathrm{FeCl}_{3}$ (few drops) was added, and dark green color appeared, which confirmed the presence of condensed tannin [13].

\section{Test for saponin}

Observation of stable foam after vigorous mixing and warming of $5 \mathrm{ml}$ aqueous extracts with $5 \mathrm{ml}$ distilled water indicated the presence of saponin [13].

\section{Test for flavonoids}

Acid extract $(2 \mathrm{ml})$ was added in sodium hydroxide solution $(2 \mathrm{ml})$, yellow precipitate was observed, which confirmed the presence of flavonoids [13].

\section{Test for anthraquinone}

Methanolic extract $(2 \mathrm{ml})$ was heated with chloroform and mixed with $1 \mathrm{ml}$ of ammonium hydroxide. Observation of rose red color confirmed the presence of anthraquinone [14].

\section{Test for glycosides}

Few drops of Molisch reagent $10 \%$ alcoholic solution of alphanaphthol) were added in $2 \mathrm{ml}$ of aqueous extract, and then, sulfuric acid was added drop by drop along the wall of the test tube. Observation of violet ring confirmed the positive test for glycosides [15].

\section{Test for sterol}

About $2 \mathrm{ml}$ of chloroform was added in $2 \mathrm{ml}$ methanol extract and heated up, and then, acetic anhydride and sulfuric acid were added. The observation of reddish-brown color confirmed the presence of sterols [15].

\section{RESULTS AND DISCUSSION}

The quantitative assessment for antimicrobial activity of the extracts was performed by measuring the diameter of ZOI at six different concentrations such as $0.2 \mathrm{~g} / \mathrm{ml}, 0.3 \mathrm{~g} / \mathrm{ml}, 0.4 \mathrm{~g} / \mathrm{ml}, 0.5 \mathrm{~g} / \mathrm{ml}, 0.6 \mathrm{~g} / \mathrm{ml}$, and $0.7 \mathrm{~g} / \mathrm{ml}$ methanol extract of both the neem and tulsi.

ZOI has been taken as absolute values neglecting $\pm 0.2 \mathrm{~mm}$ of standard error.

\section{ZOI for S. aureus}

With neem for the above-discussed concentrations, $4 \mathrm{~mm}, 7 \mathrm{~mm}, 8 \mathrm{~mm}$, $8 \mathrm{~mm}, 10 \mathrm{~mm}$, and $12 \mathrm{~mm}$ diameter, ZOI has been observed, respectively (Table 1). In tulsi for $0.2 \mathrm{~g} / \mathrm{ml}$ and $0.3 \mathrm{~g} / \mathrm{ml}$ concentrations, no ZOI was observed, whereas for other concentrations, $4 \mathrm{~mm}, 12 \mathrm{~mm}, 17 \mathrm{~mm}$, and $20 \mathrm{~mm}$ diameter ZOI was observed, respectively (Table 2). The ZOI of $8 \mathrm{~mm}$ and $4 \mathrm{~mm}$ of S. aureus from neem and tulsi at concentration $0.4 \mathrm{~g} /$ $\mathrm{ml}$ has been shown in Figs. 1 and 2, respectively.

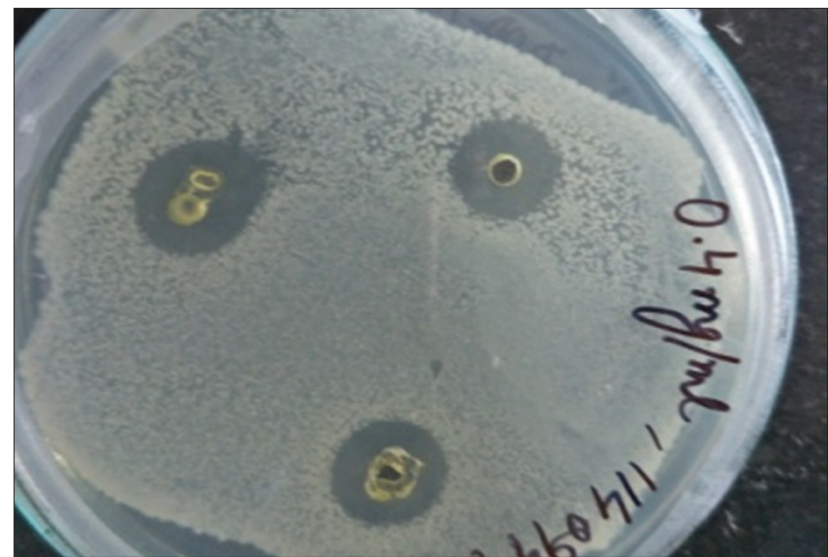

Fig. 1: ZOI of $8 \mathrm{~mm}$ of S.aureus from $0.4 \mathrm{~g} / \mathrm{ml}$ of Neem methanolic extract

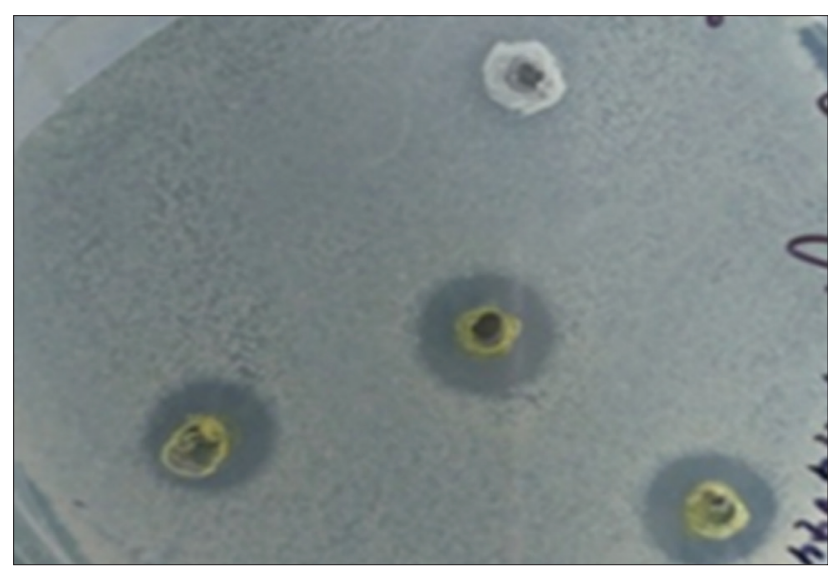

Fig. 2: ZOI of $4 \mathrm{~mm}$ of S.aureus from $0.4 \mathrm{~g} / \mathrm{ml}$ of Tulsi methanolic extract 


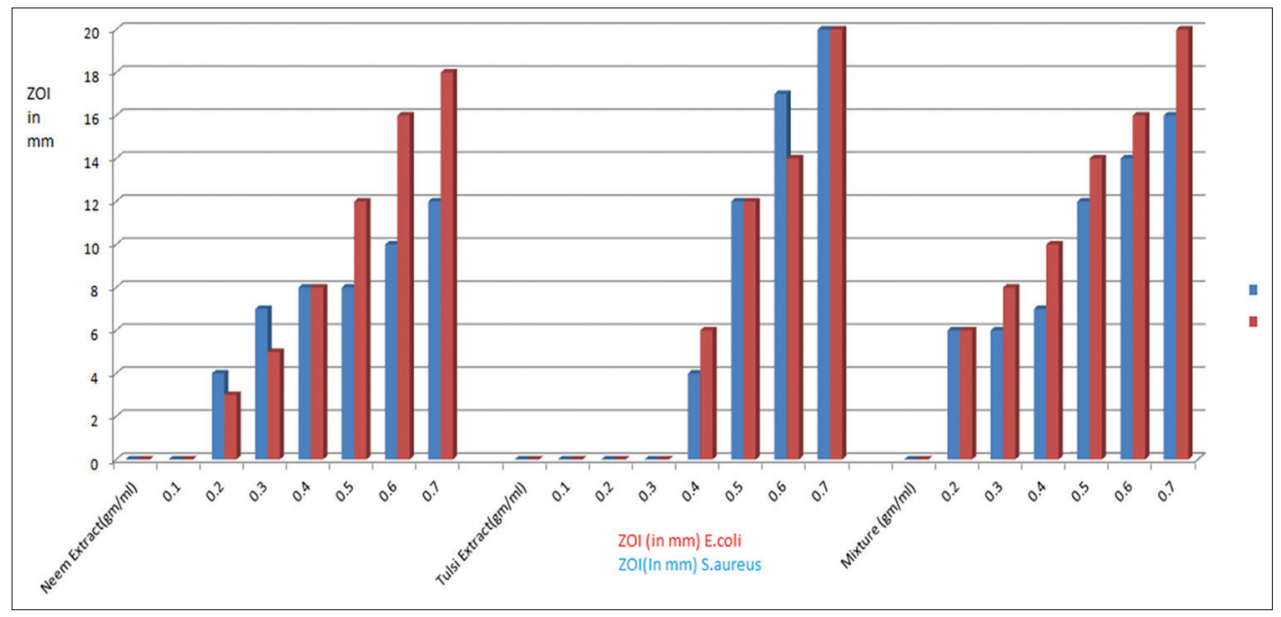

Graph 1: Comparing zone of inhibition to methanol extracts at various concentrations $(0.1-0.7 \mathrm{~g} / \mathrm{ml})$ of each extract for both the Escherichia coli and Staphylococcus aureus

Table 1: Neem methanolic leaf extracts at various concentrations $(0.2 \mathrm{~g} / \mathrm{ml}-0.7 \mathrm{~g} / \mathrm{ml})$ and their particular $\mathrm{ZOI}$ for S. aureus

\begin{tabular}{ll}
\hline Concentration (Neem) (g/ml) & ZOI (S. aureus) (mm) \\
\hline 0.2 & 4 \\
0.3 & 7 \\
0.4 & 8 \\
0.5 & 8 \\
0.6 & 10 \\
0.7 & 12 \\
\hline
\end{tabular}

S. aureus: Staphylococcus aureus, ZOI: Zone of inhibition

Table 2: Tulsi methanolic leaf extracts at various concentrations $(0.2 \mathrm{~g} / \mathrm{ml}-0.7 \mathrm{~g} / \mathrm{ml})$ and their particular $\mathrm{ZOI}$ for S. aureus

\begin{tabular}{ll}
\hline Concentration (Tulsi) (g/ml) & ZOI (S. aureus) (mm) \\
\hline 0.2 & 0 \\
0.3 & 0 \\
0.4 & 4 \\
0.5 & 12 \\
0.6 & 14 \\
0.7 & 20 \\
\hline
\end{tabular}

S. aureus: Staphylococcus aureus, ZOI: Zone of inhibition

Table 3: Neem methanolic leaf extracts at various concentrations $(0.2 \mathrm{~g} / \mathrm{ml}-0.7 \mathrm{~g} / \mathrm{ml})$ and their particular $\mathrm{ZOI}$ for E. coli

\begin{tabular}{ll}
\hline Concentration (Neem) (g/ml) & ZOI (E. coli) (mm) \\
\hline 0.2 & 2 \\
0.3 & 5 \\
0.4 & 8 \\
0.5 & 12 \\
0.6 & 16 \\
0.7 & 18 \\
\hline
\end{tabular}

ZOI: Zone of inhibition, E. coli: Escherichia coli

\section{ZOI for $E$. coli}

For the discussed concentration of neem, $2 \mathrm{~mm}, 5 \mathrm{~mm}, 8 \mathrm{~mm}, 12 \mathrm{~mm}$, $16 \mathrm{~mm}$, and $18 \mathrm{~mm}$ ZOI has been observed, respectively (Table 3). In tulsi for $0.2 \mathrm{~g} / \mathrm{ml}$ and $0.3 \mathrm{~g} / \mathrm{ml}$ concentrations, no ZOI has been observed, whereas for other concentrations, i.e., $6 \mathrm{~mm}, 12 \mathrm{~mm}$,
Table 4: Tulsi methanolic leaf extracts at various concentrations $(0.2 \mathrm{~g} / \mathrm{ml}-0.7 \mathrm{~g} / \mathrm{ml})$ and their particular $\mathrm{ZOI}$ for E. coli

\begin{tabular}{ll}
\hline Concentration (Tulsi) (g/ml) & ZOI (E. coli) (mm) \\
\hline 0.2 & 0 \\
0.3 & 0 \\
0.4 & 6 \\
0.5 & 12 \\
0.6 & 14 \\
0.7 & 20 \\
\hline
\end{tabular}

ZOI: Zone of inhibition, E. coli: Escherichia coli

Table 5: Mixture (Tulsi and Neem) leaf extracts at various concentrations $(0.2 \mathrm{~g} / \mathrm{ml}-0.7 \mathrm{~g} / \mathrm{ml})$ and their particular $\mathrm{ZOI}$ for E. coli and $S$. aureus

\begin{tabular}{lll}
\hline $\begin{array}{l}\text { Concentration } \\
\text { (Neem and Tulsi) } \mathbf{( g / m l )}\end{array}$ & E. coli $\mathbf{( m m )}$ & S. aureus $\mathbf{( m m )}$ \\
\hline 0.2 & 6 & 6 \\
0.3 & 8 & 6 \\
0.4 & 10 & 7 \\
0.5 & 14 & 12 \\
0.6 & 16 & 14 \\
0.7 & 20 & 16 \\
\hline ZOI: Zone of inhibition, E. coli: Escherichia coli, S. aureus: Staphylococcus aureus
\end{tabular}

Table 6: Results of various phytochemical tests for both the neem and tulsi

\begin{tabular}{lll}
\hline Test & Neem & Tulsi \\
\hline Flavonoid test & Present & Present \\
Tannin test & Present (condensed) & Present (condensed) \\
Froth test & Absent & Absent \\
Sterol test & Present & Present \\
Molisch test & Absent & Present \\
Anthraquinone test & Absent & Present \\
\hline
\end{tabular}

$14 \mathrm{~mm}$, and $20 \mathrm{~mm}$ diameter, ZOI has been observed, respectively (Table 4).

Mixture of tulsi and neem extract

In the case of mixture of the methanolic extracts of neem and tulsi in E. coli culture for discussed concentration $6 \mathrm{~mm}, 8 \mathrm{~mm}, 10 \mathrm{~mm}, 14 \mathrm{~mm}$, 
$16 \mathrm{~mm}$, and $20 \mathrm{~mm}$, ZOI has been observed. In S. aureus, $6 \mathrm{~mm}, 6 \mathrm{~mm}$, $7 \mathrm{~mm}, 12 \mathrm{~mm}, 14 \mathrm{~mm}$, and $16 \mathrm{~mm}$, ZOI has been observed, respectively (Tables 5 and 6).

\section{Results of phytochemical analysis}

After performing phytochemical anylsis for various secondary metabolites we have found both tulsi and neem differs from each other in terms prsenece of certain phytochemicals. Result has been shown in (Table 6).

\section{Comparative analysis}

Comparative analysis of ZOI for various concentration of tulsi and neem for E.coli and S.aureus has been done and shown in (Graph 1).

\section{Graph analysis}

Neem extract

Minimum inhibitory concentration (MIC) for both the microorganisms was found to be $0.2 \mathrm{~g} / \mathrm{ml}$. It has been observed that neem extract was more powerful against E. coli in comparison to $S$. aureus at higher concentrations. Neem was more powerful against $E$. coli than tulsi.

\section{Tulsi extract}

MIC for both the microorganisms was found to be $0.4 \mathrm{~g} / \mathrm{ml}$. About similar effect has been shown by tulsi extract on both the microorganisms. Tulsi extract has shown a more powerful effect on S. aureus than that of neem.

\section{Mixture (neem and tulsi)}

MIC for both the microorganisms was found to be $0.2 \mathrm{~g} / \mathrm{ml}$. In a mixture, we have observed that it was more powerful than that of individual extracts if we see for both the bacteria simultaneously, and ZOI was linear for both the cultures pertaining to the concentrations.

\section{CONCLUSION}

In summary, the leaf extract of both the $A$. indica and $O$. sanctum has shown antimicrobial activity against $E$. coli and $S$. aureus. The methanolic leaf extract of $A$. indica has greater antimicrobial activity against $S$. aureus, whereas the $O$. sanctum was found to be more effective against $E$. coli (indicated by the ZOI). The MIC of neem and tulsi against $E$. coli was found to be $0.2 \mathrm{~g} / \mathrm{ml}$ and $0.4 \mathrm{~g} / \mathrm{ml}$, respectively. The MIC of neem and tulsi against $S$. aureus was $0.2 \mathrm{~g} / \mathrm{ml}$ and $0.4 \mathrm{~g} / \mathrm{ml}$, respectively. When leaf extracts of neem and tulsi were mixed and their effect was observed against $E$. coli and $S$. aureus, it showed that the combination of both works more effectively against $S$. aureus as well as E. coli, and the MIC of mix extract against them was $0.2 \mathrm{~g} / \mathrm{ml}$

\section{AUTHORS' CONTRIBUTION}

All the authors have contributed equally in this project, but specifically concept of the project was formulated by Vipul Kumar and Anurag
Chakraborty, acquisition, analysis, and implementation of data have been done by all the authors equally, whereas drafting of manuscript and critical revision was done by Sony Pandey, Manpreet Kaur, and Manoj Kumar Jena. Each and every part of this project has been done under the supervision of Manoj Kumar Jena.

\section{CONFLICTS OF INTEREST}

There are no conflicts of interest among the authors declared.

\section{REFERENCES}

1. Kumar VS, Navaratnam V. Neem (Azadirachta indica): Prehistory to contemporary medicinal uses to humankind. Asian Pac J Trop Biomed 2013;7:505-14.

2. Alzohairy MA. Therapeutics role of Azadirachta indica (Neem) and their active constituents in diseases prevention and treatment. Evid Based Complement Altern Med 2016;2016:7382506.

3. Al-Jadidi HS, Hossain MA. Studies on total phenolics, total flavonoids and antimicrobial activity from the leaves crude extracts of neemtraditionally used for the treatment of cough and nausea. Beni Suef Univ J Basic Appl Sci 2015;4:2314-8535.

4. Krishnan Y, Wong NK. Cytotoxicity and antimicrobial properties of neem (Azadrichta indica) leaf extracts. Int J Pharm Pharm Sci 2015;7:975-1491.

5. Panche AN, Diwan AD, Chandra SR. Flavonoids: An overview. J Nutr Sci 2016;5:e47.

6. Pattanayak P, Behera P, Das D, Panda SK. Ocimum sanctum Linn. A reservoir plant for therapeutic applications: An overview. Pharmacogn Rev 2010;4:95105

7. Sridevi M, John B, Yaimini KA. Anti-cancer effect of Ocimum sanctum ethanolic extract in non-small cell lung carcinoma cell line. Int J Pharm Pharm Sci 2016;8:975-1491.

8. Blount ZD. The unexhausted potential of $E$. coli. Elife 2015;4:e05826.

9. Taylor EV, Nguyen TA, Machesky KD, Koch E, Sotir MJ, Bohm SR, et al. Multistate outbreak of Escherichia coli $\mathrm{O} 145$ infections associated with romaine lettuce consumption. J Food Prot 2013;76:93944.

10. Das S, Borah M, Ahmed S. Antibacterial activity of the ethanolic extract of leaves of citrus maxima (Burn) Merr. On Escherichia coli and Pseudomonas Aeruginosa. Asian J Pharm Clin Res 2013;6 Suppl 4:136-9.

11. Rajesh H. Phytochemical analysis of aqueous extract of Ocimum sanctum Linn. Int J Univ Pharm Bio Sci 2013;2:462-8.

12. Mariana C, Henrique MC, Massuco J, Taís MB, Luís VS. Phytochemical screening of Azadirachta indica A. Juss for antimicrobial activity. Afr J Microbiol Res 2017;11:117-22

13. Yamani HA, Pang EC, Mantri N, Deighton MA. Antimicrobial activity of tulsi (Ocimum tenuiflorum) essential oil and their major constituents against three species of bacteria. Front Microbiol 2016;7:681.

14. Erum I, Kamariah AS, LindaL. Phytochemical screening, total phenolics and antioxidant activities of bark and leaf extracts of Goniothalamus velutinus (Airy Shaw) from Brunei Darussalam. J King Saud Univ Sci 2015;4:224-32.

15. Rupal S, Rupesh T. Phytochemical analysis and antibacterial activity of Acacia nilotica (L.) leaves against pathogenic bacteria. Int J Green Pharm 2016;10:104-10. 